\title{
Leaf anatomical variation in Desmos Lour. and Dasymaschalon (Hook. f. \& Thomson) Dalla Torre \& Harms species (Annonaceae)
}

\author{
ISNA AROFATUN NIKMAH ${ }^{1}$, RUGAYAH RUGAYAH ${ }^{2}$, TATIK CHIKMAWATI ${ }^{3, \bullet}$ \\ ${ }^{1}$ Plant Biology Graduate Program, Department of Biology, Faculty of Mathematics and Natural Sciences, Institut Pertanian Bogor. Jl. Raya Darmaga, \\ Bogor 16680, West Java, Indonesia \\ ${ }^{2}$ Herbarium Bogoriense, Indonesia Institute of Sciences. Jl. Raya Bogor Km. 46, Cibinong, Bogor 16911, West Java, Indonesia \\ ${ }^{3}$ Department of Biology, Faculty of Mathematics and Natural Sciences, Institut Pertanian Bogor. Jl. Agathis, Kampus IPB Darmaga, Bogor16680, West \\ Java, Indonesia. Tel./fax.: +62-251-8622833, `email: tchikmawati@yahoo.com
}

Manuscript received: 5 March 2020. Revision accepted: 26 June 2020.

\begin{abstract}
Nikmah IA, Rugayah R, Chikmawati T. 2020. Leaf anatomical variation in Desmos Lour. and Dasymaschalon (Hook. $f$. \& Thomson) Dalla Torre \& Harms species (Annonaceae). Biodiversitas 21: 3317-3330. The relationships between Desmos and Dasymaschalon are debated for along time. Those two genera have high morphological similarities, especially in their generative character (moniliform monocarps). Therefore, sterile specimens of Desmos are difficult to be distinguished from Dasymaschalon. Leaf anatomy in paradermal section of 20 taxa (12 species of Desmos, eight species of Dasymaschalon) have been carried out. The data were used to support the interspecific and intergeneric delimitation of Desmos and Dasymaschalon. Desmos and Dasymaschalon are two distinct genera mainly distinguished based on the anticlinal wall undulation of epidermal cells and supported by variation of the crystal type, and size. The anticlinal wall undulation of Desmos is almost straight to slightly wavy, and never sinuous, meanwhile, Dasymaschalon varies from almost straight to deeply sinusoid. The crystals of Desmos consist of rhombohedric, druse type A, and druse type B crystals, whereas Dasymaschalon has prism, druse type A, druse type B, and drue type C crystals.
\end{abstract}

Keywords: Annonaceae, Dasymaschalon, Desmos, epidermal characteristics

\section{INTRODUCTION}

Desmos Lour. (Annonaceae) consists of about 25 species of woody climber or shrub which distributed in Asia and Australia (Sinclair 1955). Desmos is characterized by a subequal six petals arranged in two whorls and moniliform fruits (Ng 2010; Turner 2012). Several species of this genus have been used as medicinal and with ornamental purposes (Sulaiman et al. 1998; Handayani 2018). Phytochemical investigations in Desmos chinensis have shown that can be used for treatment of malaria (Kakeya et al. 1993), and has a tyrosine kinase enzyme with inhibitory property (Kakeya et al. 1993), antifungal and cytotoxic activity (Tuntipaleepun et al. 2012), anti-HIV activities (Wu et al. 2003). In general, secondary metabolites in Desmos species are terpenes (Dai et al. 2012; Connolly et al. 2005) and flavonoids (Tharikarn et al. 2011). Terpenes are compounds that have antimicrobial activity against several pathogenic bacteria such as Salmonella enterica and S. aureus (Guimarães et al. 2019), while flavonoids have antioxidant effect, modulation of the enzymatic activity and inhibition of cellular proliferation, exerting beneficial effects on the organism, as well as the use of its therapeutic potential (Jucá et al. 2020).

Dasymaschalon (Hook. f. \& Thomson) Dalla Torre \& Harms contains medium-sized trees that have singleflowered inflorescences with three petals in one whorl. This genus consists of about 30 species distributed in South-east Asia, Thailand and Peninsular Malaysia.
Dasymaschalon is closely related to Desmos molecularly and morphologically especially on their moniliform fruits (Nurmawati 2003; Wang et al. 2009; Wang 2009).

For long period of time, the relationships between Desmos and Dasymaschalon have debated (Wang et al. 2009; Ng 2010). Their flower morphology separated both genera, but they exhibit morphological similarity in their moniliform monocarps. Therefore, sterile specimens of Desmos is difficult to be distinguished from Dasymaschalon (Nurmawati 2003). Previous study on the distribution of Annonaceae in Asia-Pacific reported that there are 17 species of Desmos and 27 species of Dasymaschalon (Turner 2018). The delimitation of interand infra-genera of Desmos need to be supported by other characters. Some species of Desmos have high similarity on morphological characters, as consequently, they are sometimes difficult to be distinguished, for example, Desmos acutus (Teijsm. \& Binn.) I.M.Turner, Desmos chryseus (Miq.) Merr., and Desmos dunalii (Wall. ex Hook.f. \& Thomson) Saff. have high similarity in vegetative organs ( $\mathrm{Ng} 2010)$ or Dasymaschalon clusiflorum and D. ellipticum (Nurmawati 2003). Therefore, the anatomical characters are expected to be able to solve those species problems.

Leaf anatomy has been reported to have good taxonomical value in many plant species (Metcalfe and Chalk 1979). Recent anatomical studies in leaves of Desmos and Dasymaschalon distributed in China showed both genera were separated based on the presence or 
absence of enlarged cells in the adaxial epidermal cells, size of crystals in abaxial epidermis, bifacial or isobilateral leaves, distribution of oil cells, number of oil cells, and the structure of vascular tissue in the midrib (Sun et al. 2002). But, the taxonomy of interspecific Desmos or Dasymaschalon species that are closely related or similar morphologically has not been confirmed.

In this study, leaf anatomical analysis of some species of Desmos and Dasymaschalon distributed in Asia have been carried out to support their interspecific classification based on morphological characters. This study on leaf anatomy will have a contribution to the genera revision of Desmos and Dasymaschalon from Asian and Malesian.

\section{MATERIALS AND METHODS}

\section{Study area}

The dataset comprised 12 species of Desmos (representing ca. $43 \%$ of the species diversity of the genus in the world), eight species of Dasymaschalon (ca. 35\% of species in the world). Desmos and Dasymaschalon samples were taken from herbarium specimens, mostly from Herbarium Bogoriense (BO), and one specimen from Sandakan Herbarium (SAN). For each species were studied one or two specimens or two collection numbers from different regions depending on the availability of collected specimens (Table 1).

\section{Procedures}

The leaf anatomy of species of Dasymaschalon and Desmos were observed and compared through abaxial and adaxial leaf epidermis samples. Leaf epidermis was prepared from herbarium material following Dilcher (1974) to observe the shape and size of epidermal cells, the undulation of anticlinal cell walls of epidermal cells, the type and size of crystals, and the distribution of crystals. The shape and size of stomata were not included in this study because previous study showed that the type and size of the stomata did not provide taxonomic values for separating Dasymaschalon and Desmos. Leaf epidermis was studied by boiling the leaves in distilled water and treated overnight with a $30 \%$ solution of commercial bleach. The leaves were then washed with tap water and sliced with a razor blade to observe the abaxial and adaxial surfaces (Dilcher 1974). The lower and upper epidermal cell shapes and lengths were observed and documented using an Olympus CX21 microscope. Random observations at three different fields of view on the abaxial and adaxial epidermis were made, the constant characters, then were used as taxonomic characters for Dasymaschalon and Desmos.

\section{Data analysis}

Anatomical data was used to identify and as supporting data of two or more taxa that have high similarity morphologically. Anatomical data including epidermal cell shape, epidermal cell undulation, epidermal cell size, type of crystals in epidermal cells, size of crystals, and distribution of crystals were compared and analyzed descriptively, then scored using binary scoring to make a dendrogram in phenetic analysis using unweighted Pair Group Method with Arithmetic Mean (UPGMA). Phenetic analysis was processed using the NTSys PC 2.11 program.

\section{RESULTS AND DISCUSSION}

In this study, we found different points in separating Desmos and Dasymaschalon compared to the previous studies (Sun et al. 2002). Desmos and Dasymaschalon can be distinguished through differences in the undulation of the anticlinal wall, the type and size as well as the distribution of crystals.

Table 1. Herbarium studied specimens

\begin{tabular}{|c|c|c|}
\hline Species & Collector & $\begin{array}{l}\text { Collector } \\
\text { number }\end{array}$ \\
\hline Desmos acutus & Teysmann & 979 \\
\hline Desmos acutus & SAN & 28339 \\
\hline Desmos chinensis & AA & 648 \\
\hline Desmos chinensis & D. Soejarto & 62 \\
\hline Desmos chinensis & PK & 1757 \\
\hline Desmos cochinchinensis Lour. & L. Pierre & 638 \\
\hline Desmos chryseus & W. Grasshott & 338 \\
\hline Desmos chryseus & Teysmann & 17760 \\
\hline Desmos dumosus (Roxb.) Saff. & Leg ign & 17805 \\
\hline Desmos dunalii & BRUN & 569 \\
\hline Desmos dunalii & $\begin{array}{l}\text { Cultivated in } \\
\text { Bogor Botanical } \\
\text { Gardens }\end{array}$ & XI.A.18 \\
\hline Desmos elegans (Thwaites) Saff. & Leg ign & 17744 \\
\hline Desmos goezeanus (F.Muell.) Jessup & Gray, B. & 02847 \\
\hline $\begin{array}{l}\text { Desmos grandifolius (Finet \& } \\
\text { Gagnep.) C.Y.Wu ex P.T.Li }\end{array}$ & Leg ign & sn \\
\hline $\begin{array}{l}\text { Desmos lawii (Hook.f. \& Thomson) } \\
\text { Saff. }\end{array}$ & C. J. Saldanha & 16815 \\
\hline Desmos lawii & BC Stone & 14091 \\
\hline Desmos subbiglandulosus (Miq.) Merr. & PBU & 342 \\
\hline Desmos subbiglandulosus & AA & 1822 \\
\hline Desmos zeylanicus & Noteboom & 3190 \\
\hline $\begin{array}{l}\text { Dasymaschalon clusiflorum (Merr.) } \\
\text { Merr. }\end{array}$ & FLA & 24662 \\
\hline Dasymaschalon clusiflorum & Ampuria & sn \\
\hline $\begin{array}{l}\text { Dasymaschalon dasymaschalum } \\
\text { (Blume) I.M.Turner }\end{array}$ & $\begin{array}{l}\text { Cultivated in } \\
\text { Bogor Botanical } \\
\text { Gardens }\end{array}$ & - \\
\hline Dasymaschalon dasymaschalum & FRI & 17740 \\
\hline Dasymaschalon ellipticum Nurmawati & SAN & 114914 \\
\hline Dasymaschalon filipes (Ridl.) Bân & $\begin{array}{l}\text { E Soepadmo and } \\
\text { Mahmud }\end{array}$ & 1134 \\
\hline Dasymaschalon filipes & FRI & 32037 \\
\hline Dasymaschalon glaucum Merr. \& Chun & FC How & 73101 \\
\hline Dasymaschalon hirsutum Nurmawati & Leg ign & 74 \\
\hline $\begin{array}{l}\text { Dasymaschalon macrocalyx Finet \& } \\
\text { Gagnep. }\end{array}$ & MP & 19666 \\
\hline $\begin{array}{l}\text { Dasymaschalon wallichii (Hook.f. \& } \\
\text { Thomson) Jing Wang \& } \\
\text { R.M.K.Saunders }\end{array}$ & Teysmann & 17910 \\
\hline
\end{tabular}




\section{Epidermal cell}

The epidermal cells of abaxial and adaxial surfaces of the leaves of Desmos and Dasymaschalon are irregular or polygonal, and have thick epidermal walls. The epidermal cell size of Desmos at abaxial and adaxial surfaces are ca. $16-47 \times 10-41 \mu \mathrm{m}$ and $11-50 \times 10-43 \mu \mathrm{m}$ respectively. While the size of the epidermal cell of Dasymaschalon is ca. $18-50 \times 10-38 \mu \mathrm{m}$ (abaxial) and ca. 16-49 × 10-36 $\mu \mathrm{m}$ (adaxial) (Table 2). In this study, we found that epidermal cell size (length, size, and frequency) in each species of Desmos and Dasymaschalon are not significantly different, therefore this character is not important for taxonomical purpose. The size of epidermal cells between species and genera is not significantly different.

The epidermal cell wall undulation of Desmos varies from almost straight, slightly wavy or wavy in abaxial and adaxial surface (Figure 1, Table 2). Whereas the epidermal cell of Dasymaschalon is almost straight to deeply sinusoid on both abaxial and adaxial surfaces (Figure 1, Table 2). The abaxial and adaxial epidermal cells showed differences in anticlinal wall undulation in a species in these two genera, but sometimes they show similarity, for example in Desmos chinensis and D. dumosus, the undulation of cell walls on the abaxial and adaxial surface is almost straight. The undulation of the anticlinal wall of the epidermal cell showed the differences between genera and species, therefore it can be used as a distinguishing character among genera and species of Desmos and Dasymaschalon. Species of Desmos never show a sinuous epidermal cell, whereas four species of Dasymaschalon show a sinusoid type of undulation on the epidermal cell wall.
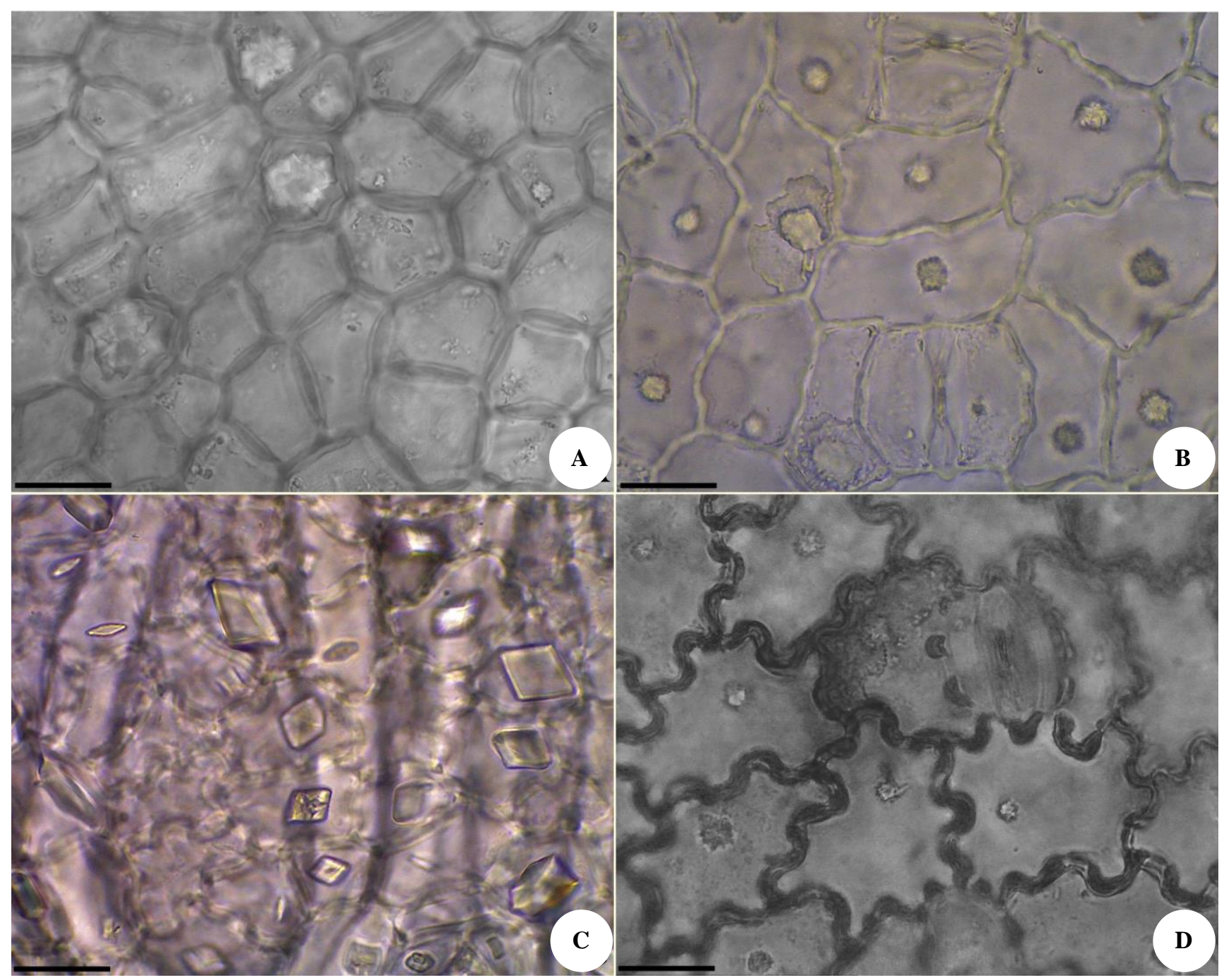

Figure 1. Variation in the anticlinal wall of epidermal cells in Desmos and Dasymaschalon. A. Almost straight in the adaxial leaf surface of Desmos chinensis. B. Slightly wavy in the adaxial leaf surface of Desmos dunalii. C. Sinuous in the adaxial leave of Dasymaschalon wallichii. D. Deeply sinuous in the abaxial leaf surface of Dasymaschalon filipes. Scale bar=20 $\mu \mathrm{m}$. 
Table 2. Anticlinal wall and size of epidermal cells of Desmos and Dasymaschalon

\begin{tabular}{|c|c|c|c|c|}
\hline \multirow{2}{*}{ Species } & \multicolumn{2}{|r|}{ Anticlinal wall of epidermal cell } & \multicolumn{2}{|c|}{ Size $(\mu \mathrm{m})$} \\
\hline & Abaxial surface & Adaxial surface & Abaxial surface & Adaxial surface \\
\hline Desmos acutus & Slightly wavy & Slightly wavy, one enlarged cell & $19-35 \times 14-25$ & $13-37 \times 10-11$ \\
\hline Desmos chinensis & Almost straight & Almost straight, with one to three enlarged cell & $20-36 \times 10-30$ & $11-35 \times 12-30$ \\
\hline Desmos cochinchinensis & Almost straight & Almost straight, No enlarged cell & $25-40 \times 24-30$ & $15-49 \times 14-37$ \\
\hline Desmos chryseus & Slightly wavy & Slightly wavy, with one to three enlarged cell & $16-37 \times 15-22$ & $16-32 \times 12-24$ \\
\hline Desmos dumosus & Almost straight & Almost straight, with one to three enlarged cell & $19-46 \times 11-26$ & $21-34 \times 11-26$ \\
\hline Desmos dunalii & Slightly wavy & Almost straight, No enlarged cell & $31-47 \times 17-37$ & $20-32 \times 15-27$ \\
\hline Desmos elegans & Slightly wavy & Wavy, with enlarged cell & $24-40 \times 20-27$ & $21-41 \times 12-34$ \\
\hline Desmos goezeanus & Slightly wavy & th enlarged cell & $5 \times 16-34$ & $10-26$ \\
\hline Desmos grandifolius & Almost straight & Slightly wavy, with one to four enlarged cell & $20-40 \times 13-21$ & $17-51 \times 15-43$ \\
\hline Desmos lawii & Slightly wavy & Slightly wavy, with one to two enlarged cell & $24-43 \times 16-27$ & $21-33 \times 13-22$ \\
\hline Desmos subbiglandulosus & Slightly wavy & Slightly wavy, with one to two enlarged cell & $22-40 \times 19-31$ & $19-40 \times 12-39$ \\
\hline Desmos zeylanicus & Almost straight & Almost straight, with enlarged cell & $28-41 \times 18-41$ & $23-37 \times 15-31$ \\
\hline Dasymaschalon clusiflorum & Slightly wavy & Sinuous, No enlarged cell & $20-35 \times 16-24$ & $27-35 \times 17-25$ \\
\hline Dasymaschalon dasymaschalum & Almost straight & Almost straight, No enlarged cell & $20-43 \times 20-24$ & $19-30 \times 10-21$ \\
\hline Dasymaschalon ellipticum & Almost straight & Slightly wavy, No enlarged cell & $21-46 \times 9-20$ & $16-29 \times 12-19$ \\
\hline Dasymaschalon filipes & Deeply sinusoid & Deeply sinusoid, No enlarged cell & $43-47 \times 25-38$ & $28-40 \times 16-32$ \\
\hline Dasymaschalon glaucum & Almost straight & Slightly wavy, No enlarged cell & $23-38 \times 10-20$ & $19-31 \times 15-25$ \\
\hline Dasymaschalon hirsutum & Slightly wavy & Sinuous, No enlarged cell & $20-42 \times 11-29$ & $22-42 \times 18-24$ \\
\hline Dasymaschal macrocalyx & Sinuous & Sinuous, No enlarged cell & $18-30 \times 15-22$ & $26-49 \times 17-36$ \\
\hline Dasymaschalon wallichii & Sinuous & Sinuous, No enlarged cell & $28-50 \times 12-27$ & $18-33 \times 14-22$ \\
\hline
\end{tabular}

Setten and Koek-Noorman (1986) stated that cell wall undulation can be a diagnostic tool on the species level. It proves that the variation within a genus is so high, but the consistency of cell wall undulation in Desmos provides a good taxonomic character to recognize Desmos and separate them from Dasymaschalon. Anticlinal wall undulation of Desmos can be an important character when two or more different species are difficult to be distinguished morphologically. For example, a sterile specimen of Desmos from Borneo deposited in BO is very similar to D. elegans. Leaf epidermal anatomy of $D$. elegans showed sinuous undulation on the abaxial and adaxial surface. Thus, it can be confirmed that this specimen does not belong to Desmos elegans even though it is very similar morphologically. Incorrect conclusions based on morphological data solely will lead to misinterpretation that $D$. elegans can also be found in Borneo.

\section{Leaf crystals}

Several types of crystals are found in Desmos and Dasymaschalon. These crystals are distributed in both abaxial and adaxial leaves surface of Desmos and Dasymaschalon. The types of crystals found in Desmos are druse and sometime rhombohedric crystals (D. acutus). Crystals found in Dasymaschalon are druses (D. ellipticum) and prisms (D. clusiflorum, D. ellipticum, D. dasymaschalum). We divide crystal druses into three types according to the shape of the individual crystals. Desmos has two types of crystal druse, namely type A: compact crystals and having a contour with a sharp-ended projection and type B: compact crystals having a contour with a bluntended projection. Meanwhile, Dasymaschalon has three types of crystal druse, namely, type A and type B as in Desmos, and type C: druse crystals with a more loose constituent and with a blunt-ended projection, for example in Dasymaschalon macrocalyx (Figure 2). The presence of solitary or cluster crystals in Desmos and Dasymaschalon is one of the important characters of Desmos and Dasymaschalon for the taxonomy of inter- and infrageneric. All species of Desmos have druse type A or type B crystals. Rhombohedric crystals can be found in $D$. acutus, D. chinensis, D. cochinchinensis, D. chryseus. Whereas some species of Dasymaschalon have solitary crystals such as prisms. Otherwise, rhombohedric crystals have never been observed in Dasymaschalon. Although Dasymaschalon species also have druses, but the number of solitary crystal that composes druse crystal in Dasymaschalon was less than Desmos, therefore we identify the druse crystal on Dasymaschalon as druse type $\mathrm{C}$ with the description as mentioned earlier. The type of crystals on the abaxial surface of Desmos can be different from the adaxial surface, for example in D. acutus which has rhombohedric crystals on the adaxial surface but not on the abaxial surface. Meanwhile, the abaxial surface of leaves of Dasymaschalon has the same type of crystals as their adaxial surface.

Crystal size varies among species of Desmos and Dasymaschalon. In genus Desmos, crystals in the abaxial surface are mostly smaller (ca. 3-17 $\mu \mathrm{m})$ than crystals in the adaxial surface (7-34 $\mu \mathrm{m}$ ) (Table 3 ). The species within the genus Desmos can be distinguished using crystal size. For closely related species with high morphological similarities, the size of the crystals can be used to support taxa delimitation. Desmos dumosus and D. subbiglandulosus are species of Desmos that are similar morphologically, but the crystal size is different. Crystals of D. dumosus are smaller than D. subbiglandulosus (4-6 $\mu \mathrm{m}$ vs $9-16 \mu \mathrm{m}$ on the abaxial surface and $10-16 \mu \mathrm{m}$ vs 20-24 $\mu \mathrm{m}$ on the adaxial surface. Meanwhile, the size of 
crystals in the abaxial and adaxial leaf surfaces of Dasymaschalon are not significantly different. The size of crystals in Dasymaschalon is $4-13 \mu \mathrm{m}$ on the abaxial surface and 4-16 $\mu \mathrm{m}$ on the adaxial surface.

Desmos species have crystals that are distributed in some epidermal cells, both abaxial and adaxial surfaces, except Desmos chinensis and D. dunalii (Figure 3). Whereas Dasymaschalon species have crystals in all epidermal cells, except Dasymaschalon clusiflorum, D. ellipticum, D. hirsutum, and D. wallichii (Figure 3). Previous studies stated that the distribution of crystals is important for delimiting genera (Setten and Koek-Noorman
1986) especially in Desmos and Dasymaschalon (Sun et al. 2002). However, in this study, We found that several specimens in one species have different crystal distribution. The adaxial surface of some specimens of Desmos chinensis and D. dunalii consists of druse crystals in all epidermal cells, but in other specimens were distributed in a few cells. However, most species of Desmos have crystals in only a few epidermal cells, and most species of Dasymaschalon have crystals in all epidermal cells. This character is a weak character taxonomically in providing delimitation on Desmos and Dasymaschalon.

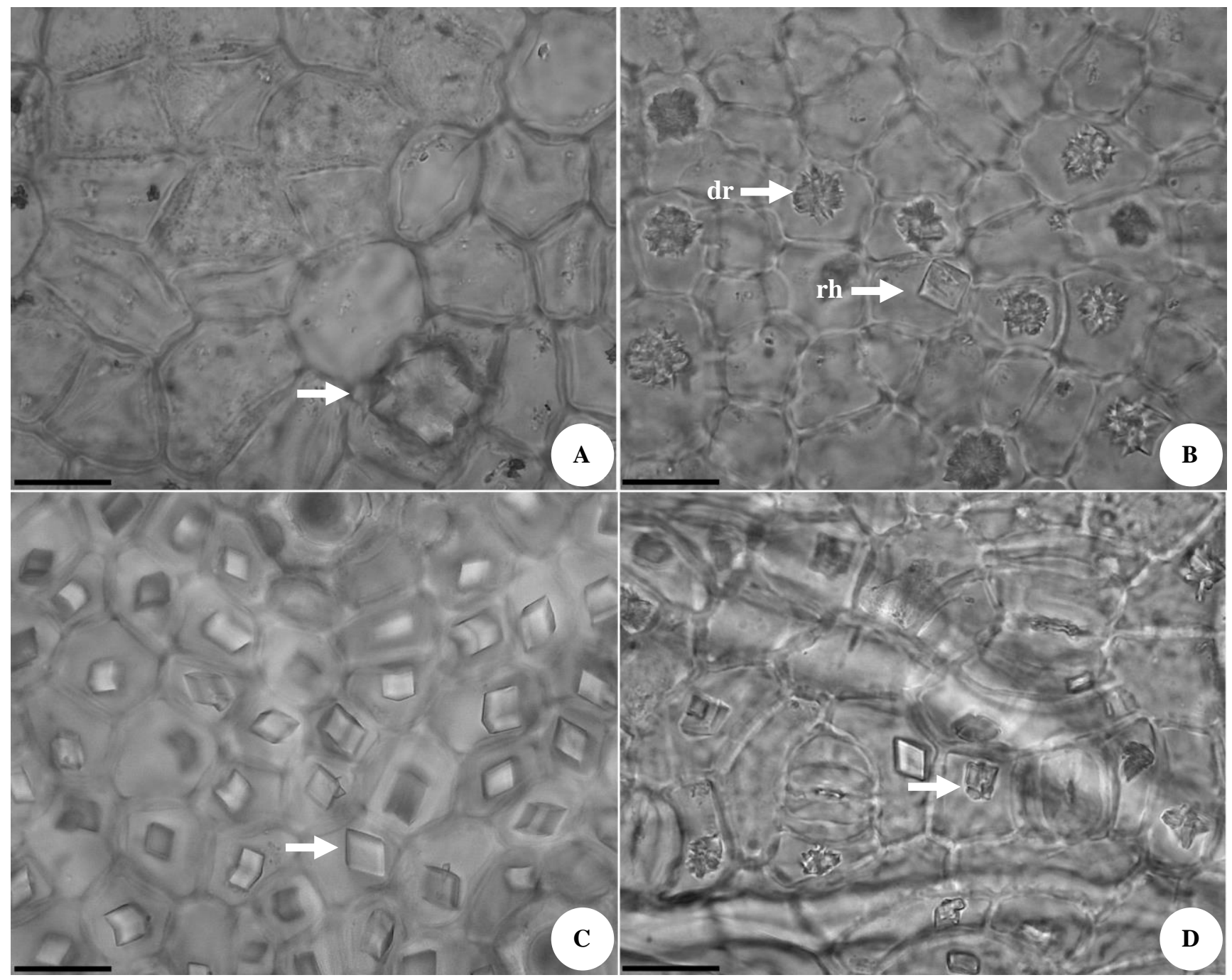

Figure 2. Variation in the crystal type in Desmos and Dasymaschalon. A. Large druse type B in Desmos chinensis. B. Rhombohedric (rh) and druse type A (dr) crystal in Desmos acutus. C. Prism crystals in Dasymaschalon dasymaschalum. D. Druse type C crystals in Dasymaschalon ellipticum. Scale bar $=20 \mu \mathrm{m}$. 


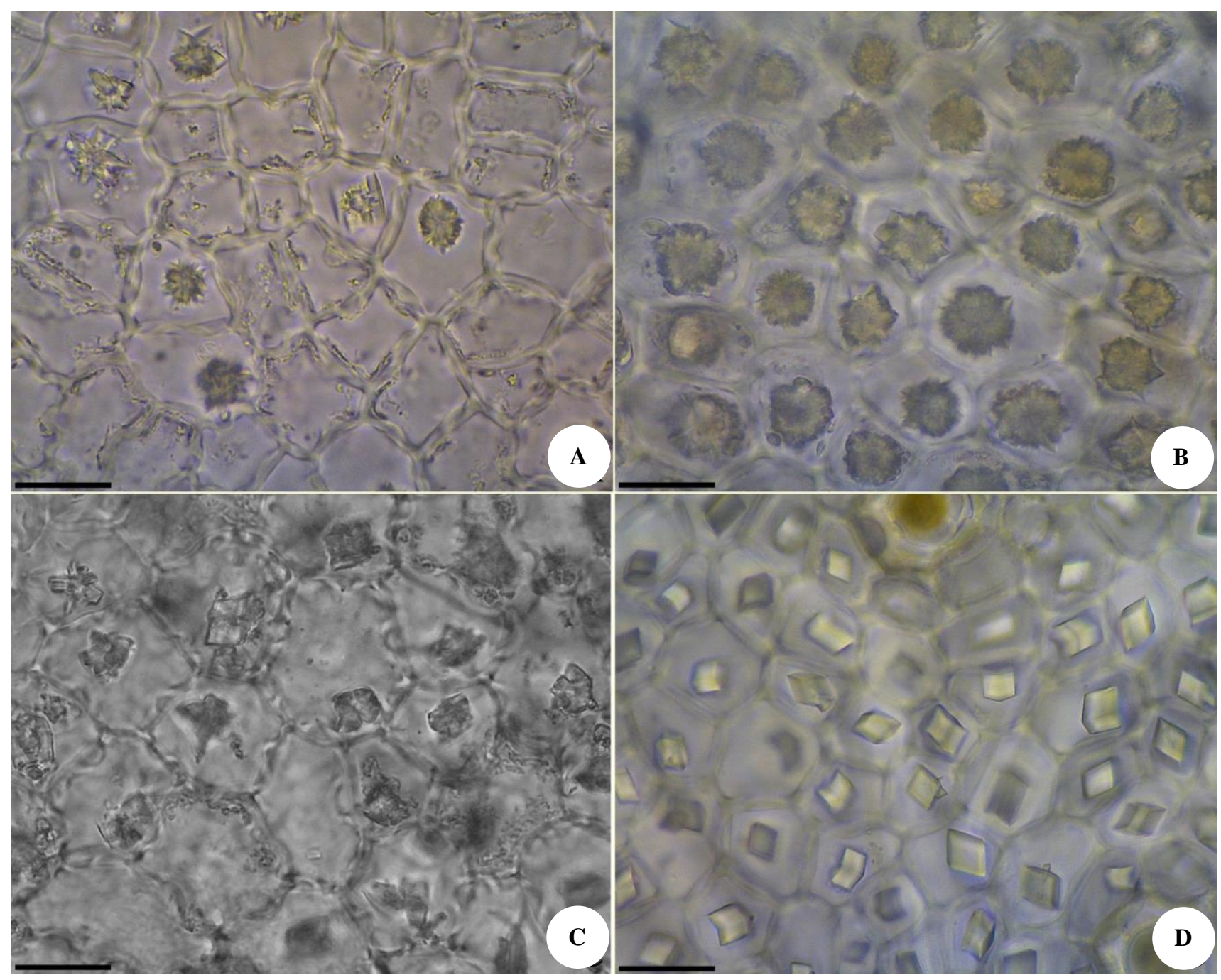

Figure 3. Distribution of crystals in Desmos and Dasymaschalon. A. Druse type A crystals distributed in some epidermal cells of Desmos goezeanus. B. Druse type B crystals distributed in all epidermal cells of Desmos dunalii. C. Druse type C crystals distributed in some epidermal cells of Dasymaschalon hirsutum. D. Prism crystals distributed in all epidermal cells of Dasymaschalon dasymaschalum. Scale bar $=20 \mu \mathrm{m}$

\section{Anatomical description in relation to taxonomy of interspecific Desmos and Dasymaschalon}

Desmos acutus

The epidermal cells of Desmos acutus are irregular shaped, slightly wavy on the abaxial and adaxial surface with the length and width are 19-35 × 14-25 and 13-37 × $10-11 \mu \mathrm{m}$, respectively. The abaxial surface contains druse type A crystals, whereas the adaxial surface contains druse type B and rhombohedric crystals with $19-26 \mu \mathrm{m}$ in diameter. Examination on Desmos acutus from Sabah with morphological variations in fruit color, stipe length, and stipe texture, showed that there was a small styloid crystal on the adaxial leaves surface. Anatomical characters of $D$. acutus showed high similarities with leaf anatomy of $D$. chryseus which is $16-32 \times 12-24 \mu \mathrm{m}$ on the adaxial surface, and slightly wavy undulation on the adaxial anticlinal wall. The adaxial surface of leaves consists of two types of crystal, namely druse type A and rhombohedric crystals. So far, rhombic crystals only found in D. chryseus, D. acutus, D. cochinchinensis, and D. chinensis (Ng 2010). Desmos acutus and D. chryseus have high morphological similarities such as leaf shape, leaf base, leaf apex, flower position and petals shape. Based on this evidence, Desmos acutus and D. chryseus may be the same species.

\section{Desmos chinensis}

The epidermal cell of Desmos chinensis is irregular shaped, almost straight on the abaxial and adaxial surface with the length and width are $20-36 \times 10-30$ and $11-35 \times$ 12-30, respectively. The abaxial and adaxial surfaces contain druse type $\mathrm{B}$ crystals. The diameter of druses in abaxial surface is $7-13 \mu \mathrm{m}$ and $24-33 \mu \mathrm{m}$ in adaxial surface. Desmos chinensis has high similarities with $D$. lawii morphologically. Desmos lawii has been treated as a synonym of $D$. chinensis, but the crystal size on the abaxand adaxial surface of leaves of these two species are different (4-9 vs 7-13 $\mu \mathrm{m}$ on the abaxial surface, and 20- 
23 vs $24-33 \mu \mathrm{m}$ on the adaxial surface). The types of crystal on the abaxial surface of these two species are also different, druse types $\mathrm{A}$ in $D$. lawii and druse type B crystals in D. chinensis. The morphology of these two species is different in their leaf size and outer petals shape consistently. These epidermal anatomy characters confirmed the separation of Desmos chinensis and D. lawii.

\section{Desmos cochinchinensis}

The epidermal cells of Desmos cochinchinensis are irregular shaped, almost straight of the abaxial and adaxial surface with the length and width are 25-40 $\times 24-30 \mu \mathrm{m}$ (abaxial) and 15-49 × 14-37 $\mu \mathrm{m}$ (adaxial). The abaxial surface contains rhombic and druse type A crystals, whereas the adaxial surface contains druse type B crystals. The diameter of crystals in abaxial surface is smaller (4-9 $\mu \mathrm{m})$ than the adaxial surface $(23-32 \mu \mathrm{m})$.

\section{Desmos chryseus}

The epidermal cells are irregular shaped, slightly wavy of the abaxial and adaxial epidermal with the length and width of 16-32 × 12-24 $\mu \mathrm{m}$ (adaxial). The abaxial surface contains druse type A crystals, while the adaxial surface contains rhombic and druse type A crystals with 10-15 $\mu \mathrm{m}$ in diameter.

\section{Key to the genera and species of Desmos and Dasymaschalon based on leaf epidermal anatomy}

\section{Key to the genera of Desmos and Dasymaschalon}

1 a. Almost straight to slightly wavy abaxial and adaxial wall of epidermal cells, having one to four enlarged cells in epidermal cells on the adaxial surface, mostly druse crystals, crystals mostly distributed only in few cells, crystals up to $30 \mu \mathrm{m}$ on the adaxial surface.....

$1 \mathrm{~b}$. Almost straight to deeply sinuous abaxial and adaxial wall of epidermal cells, no enlarged cell on the adaxial surface, having prisms, styloid and druses, crystals mostly distributed in all cells, crystals less than $25 \mu \mathrm{m}$ on the adaxial surface.

\section{Dasymaschalon}

\section{Key to the species of Desmos based on leaf epidermal anatomy}

$1 \mathrm{a}$. Slightly wavy wall of cells in the abaxial epidermal ....

$1 \mathrm{~b}$. Almost straight wall of cells in the abaxial epidermal

a Slightly wavy wall of cells in the adaxial epidermal .........

$2 \mathrm{~b}$. Wavy wall of cells in the adaxial epidermal

3 a. Almost straight wall of cells in the adaxial epidermal

$3 \mathrm{~b}$. Slightly wavy wall of cells in the adaxial epidermal

4 a. Druse type A crystals in the abaxial epidermal

4 b. Druse type B crystals in the abaxial epidermal

5 a. Druse type B crystals in the adaxial epidermal with $18-24 \mu \mathrm{m}$ in diameter.

$5 \mathrm{~b}$. Druse type A crystals in the adaxial epidermal with $30-34 \mu \mathrm{m}$ in diameter....

6 a. Druse type B crystals in the abaxial epidermal

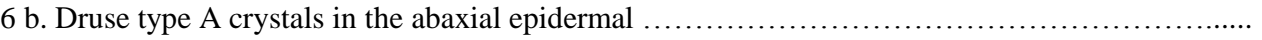

7 a. With rhombohedric crystals in the adaxial epidermal

$7 \mathrm{~b}$. Without rhombic crystals in the adaxial epidermal

8 a. Druse type B crystals in the adaxial epidermal with $16-20 \mu \mathrm{m}$ in diameter.

8 b. Druse type B crystals in the adaxial epidermal with $20-24 \mu \mathrm{m}$ in diameter

9 a. Druse type B crystals in the adaxial epidermal with $24-33 \mu \mathrm{m}$ in diameter.

9 b. Druse type A crystals in the adaxial epidermal with $7-20 \mu \mathrm{m}$ in diameter.....

10 a. Druse type B crystals in the adaxial epidermal with less than $20 \mu \mathrm{m}$ in diameter $(10-16 \mu \mathrm{m}) \ldots$.

10 b. Druse type B crystals in the adaxial epidermal with more than $20 \mu \mathrm{m}$ in diameter $(23-32 \mu \mathrm{m})$..

11 a. Druse type B crystals and sometimes with small styloid crystals in the adaxial epidermal.......

11 b. Druse type A crystals without small styloid crystals in the adaxial epidermal.

2

3

4

5

6

Desmos grandifolius

7

8

Desmos elegans

Desmos goezeanus

9

10

11

Desmos lawii

Desmos dunalii

Desmos subbiglandulosus

Desmos chinensis

Desmos zeylanicus

Desmos dumosus

Desmos cochinchinensis

Desmos acutus

Desmos chryseus

\section{Key to the species of Dasymaschalon based on leaf epidermal anatomy}

1 a. Prism and druse type $B$ crystals in the adaxial epidermal.

$1 \mathrm{~b}$. Prism or druse type A or druse type $\mathrm{C}$ crystals in the adaxial epidermal

2 a. Deeply sinusoid in the abaxial epidermal.

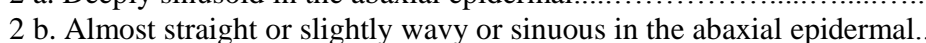

3 a. Only prism or only druse type $\mathrm{C}$ crystals in abaxial and adaxial epidermal

$3 \mathrm{~b}$. Prism and druse type $\mathrm{C}$ crystals in abaxial and adaxial epidermal

4 a. Almost straight in the adaxial epidermal.

$4 \mathrm{~b}$. Sinuous in the adaxial epidermal.

5 a. Crystals distributed in some epidermal cell.

5 b. Crystals distributed in all epidermal cell.....

6 a. Crystals distributed in some epidermal cell.

6 b. Crystals distributed in all epidermal cell

7 a. Druse type $C$ crystals, $5-11 \mu \mathrm{m}$ abaxially, and $8-16 \mu \mathrm{m}$ adaxially

7 b. Prism crystals, $4-11 \times 3-9 \mu \mathrm{m}$ abaxially and 5-10 $\times 5-9 \mu \mathrm{m}$ adaxially.
Dasymaschalon clusiflorum 2 Dasymaschalon filipes

3

4

5

Dasymaschalon dasymaschalum 6

Dasymaschalon ellipticum Dasymaschalon glaucum 7

Dasymaschalon macrocalyx Dasymaschalon hirsutum Dasymaschalon wallichii 
Table 3. Type, size, and distribution of crystal in Desmos and Dasymaschalon

\begin{tabular}{|c|c|c|c|c|c|}
\hline \multirow[b]{2}{*}{ Species } & \multicolumn{2}{|c|}{ Crystal type } & \multicolumn{2}{|c|}{ Crystal size $(\mu \mathrm{m})$} & \multirow[b]{2}{*}{ Crystal distribution } \\
\hline & Abaxial surface & Adaxial surface & $\begin{array}{l}\text { Abaxial } \\
\text { surface }\end{array}$ & $\begin{array}{c}\text { Adaxial } \\
\text { surface }\end{array}$ & \\
\hline Desmos acutus & Druse type A & $\begin{array}{l}\text { Rhombohedric; } \\
\text { Druse type B }\end{array}$ & $5-9$ & $19-26$ & Some epidermal cell and enlarged cell \\
\hline Desmos chinensis & Druse type B & Druse type B & $7-13$ & $24-33$ & Some epidermal cell and enlarged cell \\
\hline Desmos cochinchinensis & $\begin{array}{l}\text { Druse type A, } \\
\text { Rhombohedric }\end{array}$ & Druse type B & $4-9$ & $23-32$ & Some epidermal cell \\
\hline Desmos chryseus & Druse type A & $\begin{array}{l}\text { Druse type A, } \\
\text { Rhombohedric }\end{array}$ & $5-8$ & $10-15$ & Some epidermal cell \\
\hline Desmos dumosus & Druse type A & Druse type B & $4-6$ & $10-16$ & Some epidermal cell and enlarged cell \\
\hline Desmos dunalii & Druse type B & $\begin{array}{l}\text { Druse type B, } \\
\text { Rhombohedric }\end{array}$ & $6-7$ & $16-20$ & All epidermal cell \\
\hline Desmos elegans & Druse type A & Druse type B & $4-6$ & $18-24$ & Some epidermal cell and enlarged cell \\
\hline Desmos goezeanus & Druse type A & Druse type A & $4-5$ & $30-34$ & Some epidermal cell \\
\hline Desmos grandifolius & Druse type A & Druse type B & $2-7$ & $28-34$ & Some epidermal cell and enlarged cell \\
\hline Desmos lawii & Druse type A & Druse type B & $4-9$ & $20-23$ & Some epidermal cell and enlarged cell \\
\hline Desmos subbiglandulosus & Druse type B & Druse type B & $9-16$ & $20-24$ & All epidermal cell \\
\hline Desmos zeylanicus & Druse type B & Druse type A & $9-17$ & $7-20$ & Some epidermal cell and enlarged cell \\
\hline Dasymaschalon clusiflorum & $\begin{array}{l}\text { Prism, Druse type } \\
\text { A }\end{array}$ & $\begin{array}{l}\text { Prism (mostly), } \\
\text { Druse type B }\end{array}$ & $4-6$ & $\begin{array}{l}4-10 \times 8- \\
13\end{array}$ & Some epidermal cell \\
\hline $\begin{array}{l}\text { Dasymaschalon } \\
\text { dasymaschalum }\end{array}$ & Prism & Prism & $4-6 \times 3-6$ & $5-8 \times 4-7$ & All epidermal cell \\
\hline Dasymaschalon ellipticum & $\begin{array}{l}\text { Prism, Druse type } \\
\text { C }\end{array}$ & Prism, Druse type C & $\begin{array}{l}1-5 \times 1-3 \\
\text { (prisma), } \\
5-8 \text { (druse) }\end{array}$ & $\begin{array}{l}6-11 \times 3-6 \\
\text { (prism), 7- } \\
11 \text { (druse) }\end{array}$ & Some epidermal cell \\
\hline Dasymaschalon filipes & Druse type A & Druse type A & $4-6$ & $6-8$ & All epidermal cell \\
\hline Dasymaschalon glaucum & Prism, Druse type C & Prism, Druse type C & $4-7$ & $7-15$ & All epidermal cell \\
\hline Dasymaschalon hirsutum & Druse type $\mathrm{C}$ & Druse type C & $5-11$ & $8-16$ & Some epidermal cell \\
\hline Dasymaschalon macrocalyx & Druse type C & Druse type C & $8-13$ & $5-13$ & All epidermal cell \\
\hline Dasymaschalon wallichii & Prism & Prism & $4-11 \times 3-9$ & $5-10 \times 5-9$ & Almost all epidermal cell \\
\hline
\end{tabular}

\section{Desmos dumosus}

The epidermal cell of Desmos dumosus are irregular shaped, almost straight on the abaxial and adaxial epidermal with the length and width are 19-46 × 11-26 $\mu \mathrm{m}$ (abaxial) and 21-34 × 11-26 $\mu \mathrm{m}$ (adaxial). The abaxial surface contains druse type A crystals, and the adaxial surface contains druse type B crystals. The diameter of crystals in abaxial surface is $4-6 \mu \mathrm{m}$ and $10-16 \mu \mathrm{m}$ in adaxial surface. This character is different from its closely related species, Desmos subbiglandulosus. Desmos dumosus, D. subbiglandulosus, and D. cochinchinensis have similarities mainly in the density of indumentum on

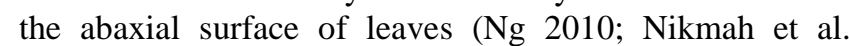
2019), but they differ in anatomical characters, such as the undulation of the abaxial and adaxial epidermal cells, type and size of crystals on the abaxial and adaxial epidermal cell.

\section{Desmos dunalii}

The epidermal cell of Desmos dunalii are irregular shaped, slightly wavy of the abaxial and adaxial epidermal with the length and width are 31-47 × 17-37 $\mu \mathrm{m}$ (abaxial), and 20-32 × 15-27 $\mu \mathrm{m}$ (adaxial). The abaxial and adaxial surfaces contain druse type $B$ crystals. The diameter of crystals on the abaxial surface is 6-7 $\mu \mathrm{m}$ and $16-20 \mu \mathrm{m}$ in adaxial surface. In this species, crystals are distributed in all abaxial and adaxial epidermal cells. This character is usually found in Dasymaschalon. Anatomical characters can be used to distinguish $D$. dunalii from its closely related species, D. acutus.

\section{Desmos elegans}

The epidermal cells of Desmos elegans are irregular shaped, 24-40 × 20-27 $\mu \mathrm{m}$ (abaxial) and 21-41 × 12-34 $\mu \mathrm{m}$ (adaxial), slightly wavy on the abaxial surface and wavy on the adaxial surface. The abaxial surface contains druse type A crystals and adaxial surface contains druse type B crystals. The diameter of crystals in abaxial surface are 4-6 $\mu \mathrm{m}$ and 18-24 $\mu \mathrm{m}$ in adaxial surface. The undulation of epidermal cells is different from the closely related species, Desmos zeylanicus. Desmos elegans and D. zeylanicus are distinguished by leaf size morphologically. However, the undulation of cell wall (slightly wavy vs almost straight) confirms that these two species are different species. The type of druse crystal also distinguishes Desmos elegans from D. zeylanicus (druse type A vs druse type B crystals on the abaxial surface and druse type B crystals vs druse type A on the adaxial surface).

\section{Desmos goezeanus}

The epidermal cells of Desmos goezeanus are irregular shaped, 17-35 × 16-34 $\mu \mathrm{m}$ (abaxial) and 17-29 × 10-26 $\mu \mathrm{m}$ (adaxial), slightly wavy on the abaxial surface and wavy on the adaxial surface. The abaxial and adaxial surfaces contain druse type A crystals. The diameter of crystals in abaxial surface is $4-5 \mu \mathrm{m}$ and $30-34 \mu \mathrm{m}$ in adaxial surface. Australian species do not have significant differences with the Asian species of Desmos anatomically. 


\section{Desmos grandifolius}

The epidermal cells of Desmos grandifolius are irregular shaped, almost straight on the abaxial surface and slightly wavy on the adaxial surface, with the length and width are 20-40 × 13-21 $\mu \mathrm{m}$ (abaxial) and 17-51 × 15-43 $\mu \mathrm{m}$ (adaxial). The abaxial surface contains druse type A and adaxial surface contain druse type B crystals. The diameter of crystals in abaxial surface is $2-7 \mu \mathrm{m}$ and $28-34$ $\mu \mathrm{m}$ in adaxial surface.

\section{Desmos lawii}

The epidermal cells of Desmos lawii are irregular shaped, slightly wavy on the abaxial and adaxial surface, 24-43 × 16-27 $\mu \mathrm{m}$ (abaxial) and 21-33 × 13-22 $\mu \mathrm{m}$ (adaxial). The abaxial surface contains druse type A and adaxial surface contains druse type $B$ crystals. The diameter of crystals in abaxial surface is $4-9 \mu \mathrm{m}$ and $20-23$ $\mu \mathrm{m}$ in adaxial surface.

\section{Desmos subbiglandulosus}

The epidermal cells of Desmos subbiglandulosus are irregular shaped, slightly wavy of abaxial and adaxial surface. The abaxial and adaxial surfaces contain druse type B crystals. The diameter of crystals in abaxial surface is $9-16 \mu \mathrm{m}$ and $20-24 \mu \mathrm{m}$ in adaxial surface. This species has a similarity with Desmos cochinchinensis morphologically, which has a very densely hairy indumentum on the abaxial surface of the leaves. Desmos cochinchinensis is distributed in Vietnam and Cambodia, while $D$. subbiglandulosus is distributed in Borneo, Peninsular Malaysia, and Sumatra. Desmos subbiglandulosus and D. cochinchinensis differ anatomically on the undulation of abaxial and adaxial anticlinal cell wall (slightly wavy vs almost straight). The epidermal cell of Desmos subbiglandulosus contains druse type B crystals on the abaxial and adaxial surface. The occurrence of druse type $B$ crystals in abaxial surface of leaves can also distinguish this species from $D$. cochinchinensis which has druse type A and rhombohedric crystal. The size of crystals can also distinguish D. subbiglandulosus and D. cochinchinensis (20-24 $\mu \mathrm{m}$ vs 4-11 $\mu \mathrm{m})$.

\section{Desmos zeylanicus}

The epidermal cells of Desmos zeylanicus are irregular shaped, almost straight of the abaxial and adaxial surface, with the length and width are $28-41 \times 18-41 \mu \mathrm{m}$ (abaxial) and 23-37 $\times 15-31 \mu \mathrm{m}$ (adaxial). The abaxial surface contains druse type $\mathrm{B}$ crystals while the adaxial surface contains druse type A crystals. The diameter of crystals in abaxial surface are 9-17 $\mu \mathrm{m}$ and $7-20 \mu \mathrm{m}$ in adaxial surface.

\section{Dasymaschalon clusiflorum}

The epidermal cells of Dasymaschalon clusiflorum are irregular shaped, sinuous with the length and width of 27 $35 \times 17-25 \mu \mathrm{m}$ (adaxial). The abaxial surface contains prism and druse type A crystals while the adaxial surface contains prism $(4-10 \times 8-13 \mu \mathrm{m}$ in length and width respectively) and druse type $B$ crystals, but the prism crystals are more abundant than druse crystals.

\section{Dasymaschalon dasymaschalum}

The epidermal cells of Dasymaschalon dasymaschalum are irregular shaped, almost straight of the abaxial and adaxial surface, with the length and width of $20-43 \times 20$ $24 \mu \mathrm{m}$ (abaxial), and 19-30 × 9-20 $\mu \mathrm{m}$ (adaxial). The leaves contain prism crystals on the abaxial and adaxial surface with the length and width of 4-6 6 3-6 $\mu \mathrm{m}$ (abaxial), and 5-8 × 4-7 $\mu \mathrm{m}$ (adaxial). Dasymaschalon dasymaschalum is the most widely distributed species.

\section{Dasymaschalon ellipticum}

The epidermal cells of Dasymaschalon ellipticum are irregular shaped, almost straight on the abaxial surface and wavy on the adaxial surface, with the length and width of 21-46 × 9-20 $\mu \mathrm{m}$ (abaxial) and 16-29 × 12-19 $\mu \mathrm{m}$ (adaxial). The abaxial and adaxial surface of leaves contains prism and druse crystals. The length and width of prism crystals are $1-5 \times 1-3 \mu \mathrm{m}$ (abaxial) and 6-11 × 3-6 $\mu \mathrm{m}$ (adaxial). While the diameter of druse crystals are 5-8 $\mu \mathrm{m}$ (abaxial) and 7-11 $\mu \mathrm{m}$ (adaxial). Dasymaschalon ellipticum is closely related to Dasymaschalon clusiflorum based on the same type of monocarps and the petiole length (Nurmawati 2003). Leaf anatomy confirms that Dasymaschalon ellipticum is distinct species with Dasymaschalon clusiflorum based on the undulation of anticlinal wall (almost straight vs. sinuous), the type of crystals on the abaxial surface (prism and druse type C crystals vs mostly prism crystals).

\section{Dasymaschalon filipes}

The epidermal cells of Dasymaschalon filipes are irregular shaped, deeply sinusoid of the abaxial and adaxial surface, with the length and width of 43-47 $\times 25-38 \mu \mathrm{m}$ (abaxial) and 28-40 × 16-32 $\mu \mathrm{m}$ (adaxial). The abaxial and adaxial surfaces contain druse type A crystals with 4-6 $\mu \mathrm{m}$ and $6-8 \mu \mathrm{m}$ in diameter, respectively. This species is the most distinct and most easily recognized species based on the length of the pedicel, which is about $19-33 \mathrm{~cm}$ long (Nurmawati 2003), and having only one (rarely two) seeds in each monocarp (Wang et al. 2009). Dasymaschalon filipes are also the most different anatomically, from the other Dasymaschalon species observed, because the undulation of anticlinal cell wall is deeply sinusoid on the abaxial and adaxial surface. The epidermal cells contain druse crystals on the abaxial surface $(4-6 \mu \mathrm{m})$ and druse type A crystals on the adaxial surface $(6-8 \mu \mathrm{m})$.

\section{Dasymaschalon glaucum}

The epidermal cells of Dasymaschalon glaucum are irregular shaped, almost straight on the abaxial surface, and slightly wavy on the adaxial surface, with the length and width of 23-38 × 10-20 $\mu \mathrm{m}$ (abaxial), and 19-31 × 15-25 $\mu \mathrm{m}$ (adaxial). The abaxial and adaxial of surface contain prism and druse type $C$ crystals with 4-7 $\mu \mathrm{m}$ in diameter on the abaxial surface and $7-15 \mu \mathrm{m}$ in diameter on the adaxial surface. Crystals are distributed in all epidermis cells. Dasymaschalon glaucum shares several morphological characters with $D$. acuminatum and $D$. sootepense, but we did not observe the epidermal leaves of 
D. acuminatum and D. sootepense. However, Wang et al. (2009) explain their morphological differences in detail.

\section{Dasymaschalon hirsutum}

The epidermal cells of Dasymaschalon hirsutum are irregular shaped, slightly wavy on the abaxial surface, and sinuous on the adaxial surface. The length and width are 20-42 × 11-29 $\mu \mathrm{m}$ (abaxial), and 22-42 × 18-24 $\mu \mathrm{m}$ (adaxial). The abaxial and adaxial surfaces contain druse type C crystals with 5-11 $\mu \mathrm{m}$ (abaxial) and 8-16 $\mu \mathrm{m}$ (adaxial) in diameter. Nurmawati (2003) stated that this species closely related to $D$. macrocalyx, and they have differed in the length of calyx. In this study, the differences only found on the abaxial surface of leaves (slightly wavy vs sinuous) and the size of crystals on the adaxial surface is not significantly different (more than $13 \mu \mathrm{m}$ vs less than 13 $\mu \mathrm{m})$

\section{Dasymaschal macrocalyx}

The epidermal cells of Dasymaschalon macrocalyx are irregular shaped, sinuous on abaxial and adaxial surface. The length and width are 18-30 × 15-22 $\mu \mathrm{m}$ (abaxial), and 26-49 $\times 17-36 \mu \mathrm{m}$ (adaxial). The abaxial and adaxial surfaces contain druse type $\mathrm{C}$ crystals with $8-13 \mu \mathrm{m}$ (abaxial) and 5-13 $\mu \mathrm{m}$ (adaxial) in diameter. Dasymaschalon macrocalyx has the same echinate pollen with Desmos (Wang 2009) but Dasymaschalon and Desmos are significantly different in their epidermal cells, mainly in the anticlinal wall undulation (sinuous without enlarged cell vs almost straight to wavy with enlarged cell). Dasymaschalon macrocalyx is the same as Dasymaschalon filipes in having few seeds per monocarp, but they differ in the pedicel length morphologically (Wang et al. 2009) and undulation of the epidermal cell wall anatomically (sinuous vs deeply sinuous) and crystal type in their adaxial leaf surface (druse type C vs. druse type A crystals).

\section{Dasymaschalon wallichii}

The epidermal cells of Dasymaschalon wallichii are irregular shaped, sinuous on the abaxial and adaxial surface. The length and width are $28-50 \times 12-27 \mu \mathrm{m}$ (abaxial) and 18-33 × 14-22 $\mu \mathrm{m}$ (adaxial). The abaxial and adaxial surface contains prism crystals with the length and width of 4-11 × 3-9 $\mu \mathrm{m}$ (abaxial) and 5-10 $\times 5-9 \mu \mathrm{m}$ (adaxial). Both palynological and morphological data showed that Dasymaschalon wallichii has the same morphological characters and pollen type as Dasymaschalon dasymaschalum (Wang 2009). The difference between these two species is only in density of the indumentum on young branches (Wang et al. 2009). However, recent anatomical data confirm that Dasymaschalon wallichii and Dasymaschalon dasymaschalum are different species as they have differences in their epidermal cell on the abaxial and adaxial surface (sinuous vs. almost straight).

\section{Phenetic analysis of Desmos using leaf epidermal characters}

The classification of Desmos and Dasymaschalon have been carried out previously based on their morphology
(Heusden 1992; Keßler 1993; Setten and Koek-Noorman 1992), pollen (Walker 1971), and molecular data (Wang et al. 2012; Guo et al. 2017). However, no information using leaf anatomical data is provided. In this study, a total of seven anatomical characters were collected from the epidermal cell of leaves of 20 taxa for the phenetic analysis. The phenetic analysis of anatomical features clarified the segregation of Desmos and Dasymaschalon. The dendrogram comprised of five groups. All Desmos species grouped in one group with a similarity coefficient of 0.414, while Dasymaschalon divided into four groups. Desmos and Dasymaschalon were separated mainly based on the differences in the crystal type. Previous research revealed that Desmos and Dasymaschalon were distinguished based on crystals distribution. Desmos crystals were only distributed in a few epidermal cells, whereas Dasymaschalon crystals were distributed in all epidermal cells. However, this study found the fact that not all Dasymaschalon specimens have crystals in all epidermal cells, and some specimens of Desmos showed crystals in all epidermal cells.

Desmos group was divided into two subgroups. Group I consist of Desmos acutus, D. chryseus, D. lawii, D. elegans, D. goezeanus, D. dunalii, D. subbiglandulosus w with a similarity coefficient of 0.488 . Whereas group II consists of Desmos chinensis, D. cochinchinensis, D. dumosus, D. grandifolius, and D. zeylanicus with a similarity coefficient of 0.432 (Figure 4 ). These two groups of Desmos were separated by the abaxial and adaxial anticlinal epidermal walls character. This clustering was different from the previous study using molecular characters that divides the Desmos according to its geographical distribution (Guo et al. 2017). In this research, the Sri Lankan species Desmos (D. elegans and D. zeylanicus) were not in one group. Likewise, Bornean Desmos (D. acutus) occurred in a group with Australian Desmos (D. goezeanus) and Indian Desmos (D. lawii) (Figure 4).

The clustering of Dasymaschalon based on anatomical characters shows the separation of Dasymaschalon into four groups. Group B consisted of Dasymaschalon ellipticum with D. glaucum with a similarity coefficient of 0.73. Group C consisted of Dasymaschalon dasymaschalum with $D$. filipes with a similarity coefficient of 0.432. Group D consists of Dasymaschalon clusiflorum and $D$. wallichii with a similarity coefficient of 0.583 . Group E consisted of Dasymaschalon hirsutum with $D$. macrocalyx with a similarity coefficient of 0.583 (Figure 4). The Dasymaschalon group was more numerous than Desmos because Dasymaschalon has a higher inter-specific variation in the character of the epidermal anticlinal wall and crystal type. The anticlinal wall in Dasymaschalon varies from almost straight, slightly wavy, sinuous, and deeply sinuous. Whereas variations in the anticlinal wall in Desmos only vary from almost straight to slightly wavy. As well as the type of crystal. Most Desmos species only have druse type A and druse type B crystals, although rhombohedric crystals were sometimes found, while the type of crystal between Dasymaschalon species varies from druse type A, druse type B, druse type $\mathrm{C}$, and prism. 


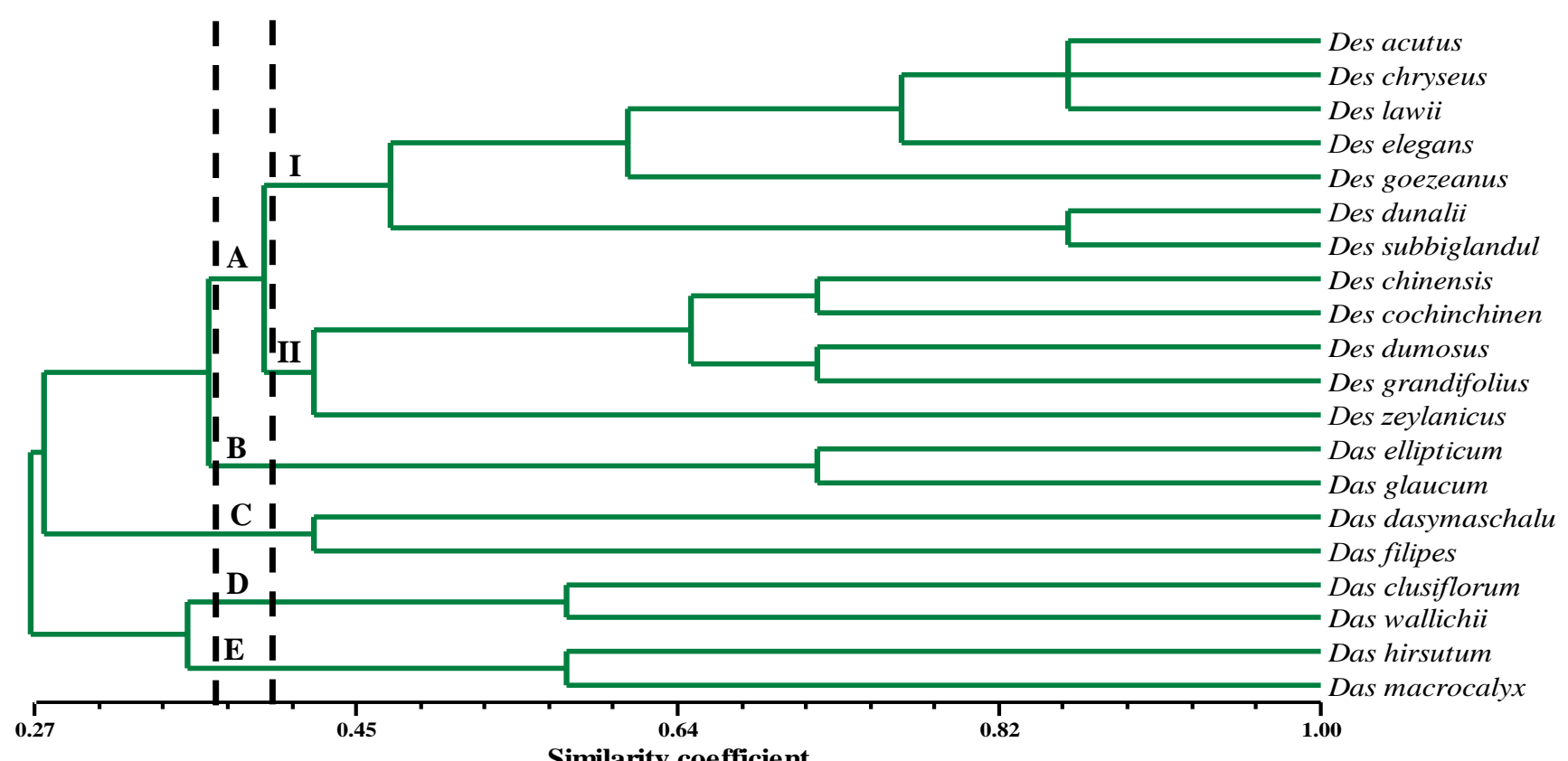

Figure 4. Dendrogram of Desmos and Dasymaschalon based on anatomical data

\section{Discussion}

The vegetative and generative morphology among species of Desmos often shows high similarities ( $\mathrm{Ng} 2010)$. Several characters that can be used to distinguish among species of Desmos are leaf lamina apex, indumentum type, and tertiary leaf venation, while similar generative characters include flowering position, length of flowering pedicels, pedicel bracts position, shape and size of sepals, length of stipes, shape of seeds ( $\mathrm{Ng} \mathrm{2010).} \mathrm{Although} \mathrm{it} \mathrm{can}$ be distinguished based on vegetative and generative characters, some species are sometimes difficult to be distinguished, especially when there are only sterile specimens found or leaves. It can lead to misidentification and finally will lead to uncorrect diversity data of species in an area. Metcalfe and Chalk (1979), stated that anatomical of leaf epidermal were useful for systematics although sometimes it was influenced by environmental factors and generally do not show high differences within species in the same genus (Dickison 2000). Therefore, information about the anatomical characters of the leaves of those genera will be important to solves the problems.

The epidermal leaf anatomy of 22 species of the Desmos and Dasymaschalon was presented. In this research, we used 12 species of Desmos and eight species of Dasymaschalon. Each species represented by two specimens to ensure that the characters used to separate these taxa are not influenced by environment. Leaf epidermal anatomy has a role as supporting data for delimitation of Desmos and Dasymaschalon through the differences in the anticlinal wall undulation of the epidermis and crystals.
In this study, it was found that all species of Desmos and Dasymaschalon have irregular shape of epidermal cells and have thick epidermal walls. Thick epidermal walls are a primitive characteristic of the Magnoliales group (Baranova 1972). The size of the epidermal cells varies greatly, however, Asian and Australian Desmos and Dasymaschalon have no differences with the members of the Neotropical Annonaceae. The epidermal cell size of Annonaceae distributed in the Neotropical region are also $15-60 \times 12-50 \mu \mathrm{m}$ (adaxial), and 15-60 × 10-40 $\mu \mathrm{m}$ (abaxial) with anticlinal cell walls straight to undulate on both leaf surfaces (Setten and Koek-Noorman 1986). In this study, epidermal cell size cannot be used to distinguish species or genera. The size of epidermal cells in the other members of Annonaceae also varies greatly, such as in Monodora (Pereira-Sheteolu 1992) and rarely shows differences between species, although in other families, the size of epidermal cells has potential for an additional taxonomic character, such as in Datura (Solanaceae) which vary from the leaves of one species to another within the genus (Ibrahim et al. 2016).

The undulation of the anticlinal wall of epidermal cells become one of the important characters to recognize and distinguish Desmos and Dasymaschalon. The undulation of anticlinal wall was constant within species and within genus. All species of Desmos, both Asian and Australian Desmos, have no sinuous anticlinal wall undulation, while some species of the Dasymaschalon have sinuous to very sinuous anticlinal walls. A deeply sinuous undulation of anticlinal wall is relatively primitive epidermal types (Baranova 1972). Variations in the undulation of the anticlinal wall have also been reported in the genus Annona 
and have taxonomic values at the species level (Folorunso and Ezekiel 2014). As in previous studies, the undulation of the anticlinal wall of epidermal cells can distinguish species in Annonaceae (Sun et al. 2001, Patel 1971), although the epidermal cell wall can also be different between mature leaves and young leaves (Patel 1971). The young leaves have thin epidermis and straight anticlinal walls (Patel 1971). There have been many studied that effectively used leaf epidermal to identify medicinal plant species of the Annonaceae (Ameyaw and Akotoye 2007, Pereira-Sheteolu 1992, Pelden and Meesawat 2019) and showed differences in its epidermal cell walls (Patel 1971, Sun et al. 2002, Ameyaw and Akotoye 2007). Epidermal characters in primitive families of Angiosperm are taxonomically useful at the level of species such as character size of the guard cells, the thickness of their walls, and the arrangement and degree of development of the cuticular thickenings on the outer and inner walls and also the form of the other epidermal cells and the degree and character of their wall-thickenings (Baranova 1972). Not only having taxonomic values, leaf anatomy in Annonaceae can also be used to determine the strategy of plants to adapt to the environment as in Xylopia aromatica that grow in the xeric environment characterized by thickened cell walls of epidermal cells and the presence of silica on the adaxial surface (Simioni et al. 2018).

In this study, it was found that the type of crystal can be an important character to distinguish species and genera. The types of crystals are genetically determined (Franceschi and Nakata 2005) therefore the crystal types in Desmos and Dasymaschalon can be used as distinguishing features of species and genera. The epidermal cell of Neotropical Annonaceae also shows that the crystal character is constant. Many publications state that crystals characters in the epidermal cells have a strong taxonomic or diagnostic value (Jovet-Ast 1942; Setten and KoekNoorman 1986). Previous studies on several genera in Annonaceae showed variation in the epidermal crystals, from cluster crystals to trihydric crystals (Ameyaw and Akotoye 2007), while previous studies on Desmos showed that it has solitary or clustered crystals (Metcalfe 1987) which consist of irregular druse crystals, comparatively

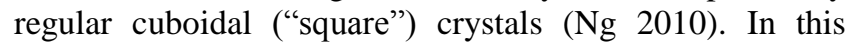
study, showed that square crystals occurred in Desmos acutus, D. chryseus, and D. cochinchinensis, but Ng (2010) reported this type of crystals was also found in $D$. chinensis. In this study, all species of Desmos have druse crystals, however, not all species of Dasymaschalon have druse crystals.

Crystal size can be used to differentiate between species and genera. Although the size of the crystal can be affected by physical, chemical, and biological parameters and herbivory (Franceschi and Horner 1980; Molano-Flores 2001; Kuo-Huang et al. 2007), but the size of the crystals in some species of Desmos and Dasymaschalon are significantly different. The size of druse crystals in Desmos can reach up to $30 \mu \mathrm{m}$ on the adaxial surface of leaves, whereas on Dasymaschalon are less than $25 \mu \mathrm{m}$ on the adaxial surface of leaves. Large size of druse crystals is also found in Friesodielsia (Nikmah 2020, unpublished data). This result supports Heusden (1992) that Desmos is more similar to Friesodielsia than Dasymaschalon.

Previous studies showed that the distribution of crystals is important character for delimiting Desmos and Dasymaschalon (Sun et al. 2002), however, the result in this study confirmed that distribution of crystal is an inconsistent character. Previous studies stated that crystals on Desmos were distributed in only to a few epidermal cells, whereas crystals on Dasymaschalon were distributed in all epidermal cells. In this study, we found that this case did not occur in all specimens. Druse crystals in Desmos chinensis specimens from Kalimantan (AA648) were distributed in all epidermal cells, as in most Dasymaschalon species, and Desmos dunalii as well. Therefore, this character is considered as a weak taxonomical character. Study on leaves of Sida (Malvaceae) found that quantity $r$ density of crystals is determined by herbivory and calcium existence (MolanoFlores 2001) and in Piperaceae is determined by light density (Kuo-Huang et al. 2007). Setten and KoekNoorman (1986) found that crystals are not only found in the epidermal cell, but also in the sponge- and palisade parenchyma.

The generic separation of Desmos and Dasymaschalon and the association of Desmos-DasymaschalonFriesodielsia in one informal group were supported by the result of this study. Desmos, Dasymaschalon, and Friesodielsia are closely related genera according to the phylogenetic study (Wang et al. 2012; Xue et al. 2019), but their floral structures are different (Chiu 2012; Guo et al. 2018). The epidermal anatomy supports a classification based on the floral morphology by Heusden (1992) who divided Annonaceae into 20 informal groups, of which Desmos, Dasymaschalon, and Friesodielsia belong to the Friesodielsia Group. The epidermal anatomy of three Friesodielsia species (Nikmah 2020, unpublished data) found that the anatomical characters of these three genera were overlapped. The undulation of anticlinal wall of Friesodielsia has similarities with Desmos and Dasymaschalon, which are almost straight (like Desmos) to sinuous (as in Dasymaschalon). Based on the type of crystal size, Friesodielsia has the same crystal druse size on the abaxial and adaxial surfaces and distributed in a few cells as in Desmos. Wang et al. (2012) stated that there was a similarity of petals between Dasymaschalon and Friesodielsia which is connective at the apex, and forming enclosed pollination chamber. Possibly this is the explanation of the similarities in epidermal anatomy of Dasymaschalon and Friesodielsia. Therefore, epidermal anatomy supports the Desmos-DasymaschalonFriesodielsia classification into one informal group. Keßler (1993) also classified Annonaceae based on flower morphology, but separated Friesodielsia from Desmos and Dasymaschalon and put it in the Pseuduvaria Group.

In conclusion, our research confirmed that Desmos and Dasymaschalon are two distinct genera that strongly separated based on the differences in epidermal cell wall undulation, type, and size of crystals, whereas crystal distribution was a weak character taxonomically to distinguish Desmos and Dasymaschalon. Additionally, 
epidermal cell wall undulation, type, and size of crystals in Desmos and Dasymaschalon can be used to delimitate two or more species that share high similarity morphologically.

\section{ACKNOWLEDGEMENTS}

The author would like to thank Bogoriense Herbarium (BO), Sandakan Herbarium (SAN) for allowing us to make herbarium specimens for anatomical preparation, and Prof Mien A. Rifai for giving us valuable comments in preparing this manuscript. Thanks also to KemenristekDIKTI for financial support.

\section{REFERENCES}

Ameyaw Y, Akotoye HK. 2007. Leaf epidermal studies of some medicinal plant species of the family Annonaceae in the Pra - Suhien forest in the central region of Ghana. Biosci Biotech Res Asia 4 (2): 441-447.

Baranova M. 1972. Systematic anatomy of the leaf epidermis in the Magnoliaceae and some related families. Taxon 21 (4): 447-469. DOI: $10.2307 / 1219106$

Chiu PC. 2012. Floral Biology, Pollination Ecology and Breeding Systems of Selected Dasymaschalon, Desmos, Pseuduvaria and Uvaria Species (Annonaceae) in Southern China and Australia. [Thesis]. The University of Hong Kong, Hong Kong.

Connolly JD, Dagli S, Haque ME. 2005. Constituents of the Annonaceae species Miliusa velutina and Desmos longiflorus. Chem Inform 36: 16. DOI: $10.1002 /$ chin. 200516155

Dai DHTM, Thang TD, Ogunwande IA. 2012. The leaf essential oils of five Vietnamese Desmos species (Annonaceae). Nat Prod Commun 7 (2): $231-234$

Dickison WC. 2000. Integrative Plant Anatomy. Academic, New York.

Dilcher DL. 1974. Approaches to the identification of Angiosperm lea remains. Bot Rev 40: 1-157. DOI: 10.1007/BF02860067.

Folorunso, Ezekiel A. 2014. Study of foliar epidermal characters and petiole anatomy of four underutilized Annona (1.) species in Nigeria Int J Curr Res 6 (11): 10013-10018.

Franceschi VR, Horner HT. 1980. Calcium oxalate crystals in plants. Bot Rev 46: 361-427.

Franceschi VR, Nakata PA. 2005. Calcium oxalate in plants: formation and function. Annu Rev Plant Biol 56 (1): 41-71. DOI 10.1146/annurev.arplant.56.032604.144106.

Guimarães AC, Meireles LM, Lemos MF, Guimarães MCC, Endringer DC, Fronza M, Scherer R. 2019. Antibacterial activity of terpenes and terpenoids present in essential oils. Molecules 24: 2471

Guo X, Hoekstra P, Tang CC, Thomas DC, Wieringa JJ, Chatrou LW, Saunders RMK. 2017. Cutting up the climbers: evidence for extensive polyphyly in Friesodielsia (Annonaceae) necessitates generic realignment across the tribe Uvarieae. Taxon 66 (1): 3-19. DOI: $10.12705 / 661.1$

Guo X, Thomas DC, Saunders RMK. 2018. Organ homologies and perianth evolution in the Dasymaschalon alliance (Annonaceae) inner petal loss and its functional consequences. Front Plant Sci 9 DOI: $10.3389 /$ fpls.2018.00174.

Handayani T. 2018. Diversity, potential and conservation of Annonaceae in Bogor Botanic Gardens, Indonesia. Biodiversitas 19 (2): 591-603. DOI: 10.13057/biodiv/d190230

Heusden ECH. 1992. Flowers of Annonaceae: morphology, classification, and evolution. Blumea Suppl 7: 1-218.

Ibrahim HM, Abdo NA, Al Masaudi ES, Al-Gifri ANA. 2016 Morphological, epidermal and anatomical properties of Datura Linn. leaf in Sana'a City-Yemen and its taxonomical significance. Asian J Plant Sci Res 6 (4): 69-80.

Jovet-Ast S. 1942. Recherches sur les Anonacées d'Indochine. Mém Mus Natl Hist Nat 16: 125-308.

Jucá MM, Cysne Filho FMS, de Almeida JC, Mesquita DDS, Barriga JRM. Dias KCF, Barbosa TM, Vasconcelos LC, Leal LKAM, Ribeiro
JE, Vasconcelos SMM. 2020. Flavonoids: biological activities and therapeutic potential. Nat Prod Res 16: 1-14

Kakeya H, Imoto M, Tabata Y, Iwami J, Matsumoto H, Nakamura K, Koyano T, Tadano K, Umezawa K. 1993. Isolation of a novel substrate-competitive tyrosine kinase inhibitor, desmal, from the plant Desmos chinensis. FEBS Lett 320 (2): 169-172. DOI: 10.1016/00145793(93)80085-9.

Keßler PJA. 1993. Annonaceae. In: Kubitzki K, Rohwer JG, Bittrich V (eds) The Families and Genera of Vascular Plants. Springer-Verlag, Berlin.

Kuo-Huang LL. Ku, MSB, Franceschi VR. 2007. Correlations between calcium oxalate crystals and photosynthetic activities in palisade cells of shade-adapted Peperomia glabella. Bot Stud 48 (2): 155-164.

Metcalfe CR, Chalk L. 1979. Anatomy of the Dicotyledons: Systematic Anatomy of the Leaf and Stem. Oxford Clarendon, Oxford.

Metcalfe CR. 1987. Anatomy of the Dicotyledons. Clarendon Press, Oxford.

Molano-Flores B. 2001. Herbivory and calcium concentrations affect calcium oxalate crystal formation in leaves of Sida (Malvaceae). Ann Bot 88 (3): 387-391. DOI: 10.1006/anbo.2001.1492

$\mathrm{Ng}$ KW. 2010. Systematics of Desmos (Annonaceae) in Thailand, Peninsular Malaysia and Sumatra. [Thesis]. The University of Hong Kong, Hong Kong.

Nikmah IA, Chikmawati T, Rugayah. 2019. Reinstatement of Desmos subbiglandulosus (Annonaceae) in Borneo. Floribunda 6 (3): 98-102.

Nurmawati S. 2003. Malesian species of Dasymaschalon (Annonaceae). Floribunda 2 (3): 67-81.

Patel RJ. 1971. Epidermal structure and development of stomata in some Annonaceae. Ann Bot 35 (5): 1205-1212. DOI: 10.1093/oxfordjournals.aob.a084554.

Pelden D, Meesawat U. 2019. Foliar idioblasts in different-aged leaves of a medicinal plant (Annona muricata L.). Songklanakarin J Sci Technol 41 (2): 414-420.

Pereira-Sheteolu AO. 1992. Taxonomy of medicinal plants: foliar epidermal characters in the genus Monodora (Annonaceae). Feddes Repert 103 (5-6): 375-379

Setten AKV, Koek-Noorman J. 1986. Studies in Annonaceae. VI. A leaf anatomical survey of genera of Annonaceae in the Neotropics. Bot Jahrb Syst 108: 17-50.

Setten AKV, Koek-Noorman J. 1992. Fruits and seeds of Annonaceae: morphology and its significance for classification and identification. Bibl Bot 142: 1-101.

Simioni PF, Pessoa MJG, Cardoso MA, Cabral FF, Teixeira SO, da Silva IV. 2018. Leaf anatomy of Xylopia aromatica (Lam.) Mart. (Annonaceae) occurring in a rocky savannah in the Brazilian Amazonian. Acta Sci Biol Sci 40 (1): $37334 . \quad$ DOI: 10.4025/actascibiolsci.v40i1.37334

Sinclair J. 1955. A revision of the Malayan Annonaceae. Gard Bull Singap 14: 149-516.

Sulaiman M, Martin MH, Pais M, Hadi AHA, Awang K. 1998. Desmosine, an artifact alkaloid from Desmos dumosus. Phytochemistry 49 (7): 2191-2192. DOI: 10.1016/S00319422(98)00378-1.

Sun T-X, Wu H, Li P-T, Sun J, Zheng X-F. 2002. Leaf anatomy of Desmos and Dasymaschalon (Annonaceae) from China in relation to taxonomic significance. JSE 40: 385-395.

Sun T-X, Zhao S, Zhuang XY, Wu H. 2001. Leaf epidermal structure in 10 species of Annonaceae. J Trop Subtrop Bot 9 (3): 194-200.

Tharikarn R, Thumnoon M, Chanita P, Wilawan M, Suda C. 2011. Saiyutones A-D: four new unusual biflavones from Desmos chinensis. Tetrahedron 67: 5444-5449.

Tuntipaleepun M, Chakthong S, Ponglimanont C, Plodpai P, Voravuthikunchai SP. 2012. Antifungal and cytotoxic substances from the stem barks of Desmos chinensis. Chin Chem Lett 23: 587590. DOI: 10.1016/j.cclet.2012.03.019.

Turner IM. 2012. Annonaceae of Borneo: a review of the climbing species. Gard Bull Sing 64 (2): 371-479.

Turner IM. 2018. Annonaceae of the Asia-Pacific region: names, types and distributions. Gard Bull Sing 70 (1): 409-744. DOI: 10.26492/gbs70(2).2018-11

Walker JW. 1971. Contributions to the pollen morphology and phylogeny of the Annonaceae I. Grana 11: 45-54. DOI: 10.1080/0017313710942741.

Wang J, Chalermglin P, Saunders RMK. 2009. The genus Dasymaschalon (Annonaceae) in Thailand. Syst Bot 34 (2): 252-265. DOI: $10.1600 / 036364409788606271$. 
Wang J, Thomas DC, Su YCF, Meinke S, Chatrou LW, Saunders RMK. 2012. A plastid DNA phylogeny of Dasymaschalon (Annonaceae) and allied genera: Evidence for generic non-monophyly and the parallel evolutionary loss of inner petals. Taxon 61 (3): 545-558.

Wang J. 2009. Systematics and Phylogeny of Dasymaschalon (Annonaceae). [Thesis]. The University of Hong Kong, Hong Kong.

Wu J-H, Wang X-H., Yi Y-H, Lee K-H. 2003. Anti-AIDS Agents 54. A Potent Anti-HIV chalcone and flavonoids from genus Desmos. Bioorg
Med Chem Lett 13: 1813-1815. DOI: 10.1016/s0960-894x(03)001975.

Xue B, Guo X, Landis JB, Sun M, Tang CC, Soltis PS, Saunders RMK 2019. Accelerated diversification correlated with functional traits shapes extant diversity of the early divergent Angiosperm family Annonaceae. Mol Phylogenet Evol 106659. DOI: 10.1016/j.ympev.2019.106659. 